\title{
CMV-specific T cell isolation from G-CSF mobilized peripheral blood: depletion of myeloid progenitors eliminates non-specific binding of MHC-multimers
}

\author{
Lorea Beloki ${ }^{1}$, Miriam Ciaurriz ${ }^{1}$, Cristina Mansilla ${ }^{1}$, Amaya Zabalza', Estela Perez-Valderrama', Edward R Samuel², \\ Mark W Lowdell ${ }^{2}$, Natalia Ramirez ${ }^{1 * \dagger}$ and Eduardo Olavarria ${ }^{1,3+}$
}

\begin{abstract}
Background: Cytomegalovirus (CMV)-specific T cell infusion to immunocompromised patients following allogeneic Hematopoietic Stem Cell Transplantation (allo-HSCT) is able to induce a successful anti-viral response. These cells have classically been manufactured from steady-state apheresis samples collected from the donor in an additional harvest prior to G-CSF mobilization, treatment that induces hematopoietic stem cell (HSC) mobilization to the periphery. However, two closely-timed cellular collections are not usually available in the unrelated donor setting, which limits the accessibility of anti-viral cells for adoptive immunotherapy. CMV-specific cytotoxic T cell (CTL) manufacture from the same G-CSF mobilized donor stem cell harvest offers great regulatory advantages, but the isolation using MHC-multimers is hampered by the high non-specific binding to myeloid progenitors, which reduces the purity of the cellular product.
\end{abstract}

Methods: In the present study we describe an easy and fast method based on plastic adherence to remove myeloid cell subsets from 11 G-CSF mobilized donor samples. CMV-specific CTLs were isolated from the non-adherent fraction using pentamers and purity and yield of the process were compared to products obtained from unmanipulated samples.

Results: After the elimination of unwanted cell subtypes, non-specific binding of pentamers was notably reduced. Accordingly, following the isolation process the purity of the obtained cellular product was significantly improved.

Conclusions: G-CSF mobilized leukapheresis samples can successfully be used to isolate antigen-specific T cells with MHC-multimers to be adoptively transferred following allo-HSCT, widening the accessibility of this therapy in the unrelated donor setting. The combination of the clinically translatable plastic adherence process to the antigen-specific cell isolation using MHC-multimers improves the quality of the therapeutic cellular product, thereby reducing the clinical negative effects associated with undesired alloreactive cell infusion.

Keywords: Allogeneic hematopoietic stem cell transplantation, Cytomegalovirus-specific cytotoxic T cells, MHC-multimers, Granulocyte-colony stimulating factor, Immunotherapy

\section{Background}

Allogeneic hematopoietic stem cell transplantation (allo-HSCT) allows the recovery of a sick hematopoietic system affected by congenital or acquired severe disorders [1]. Peripheral blood stem cells (PBSCs) are the main hematopoietic stem cell source [2], recombinant

\footnotetext{
* Correspondence: nramireh@navarra.es

${ }^{\dagger}$ Equal contributors

'Oncohematology Research Group, Navarrabiomed - Miguel Servet

Foundation, Irunlarrea 3, 31008 Pamplona, Spain

Full list of author information is available at the end of the article
}

granulocyte-colony stimulating factor (G-CSF; Filgrastim) being clinically used for the mobilization of hematopoietic stem cells (HSCs) to the periphery. This treatment enriches the sample in neutrophils, monocytes, lymphoid and myeloid progenitor cells at different stages of maturation that will be differentiated into monocytic and granulocytic lineages [3-5].

Studies of immune reconstitution after allo-HSCT have identified a decisive role of CD8+ cytotoxic T lymphocyte (CTL) recovery in preventing the development of viral diseases [6]. Amongst them, CMV infection remains a 
major complication in recipients following allo-HSCT, and the adoptive transfer of CMV-specific $\mathrm{T}$ cells has shown successful clinical results [7-12]. Several strategies have been used for anti-CMV T cell manufacture [13-17]. MHC-multimers allow the direct selection of antigenspecific CD8+ T cells with no need for long-term in vitro culture, offering a direct and fast selection strategy [18]. This avoids the functional damaging effects of the expansion, thereby preserving the survival potential and cellular properties of the therapeutic product [19-21].

Historically, the manufacture of virus-specific $\mathrm{T}$ cells for adoptive immunotherapy has involved the use of donor lymphocytes collected from a steady-state leukapheresis obtained from an additional apheresis prior to the G-CSF administration for HSC mobilization. G-CSF has previously been shown to induce immunologic tolerance; it promotes $\mathrm{T}$ helper type 2 (Th2) and regulatory T cell differentiation and downregulates genes associated with Th1 cells, cytotoxicity, antigen presentation and graft versus host disease (GvHD) [22-25]. In spite of the above described immunosuppressive effects of G-CSF treatment, recently some authors have successfully generated competent CMV-specific T cells from G-CSF mobilized apheresis samples [26,27]. CMV-specific $\mathrm{T}$ cell manufacture from the same G-CSF mobilized collection used to obtain HSCs would abrogate the need for successive donations, assuring the availability of an anti-viral cell product in the unrelated donor setting while minimizing costs and discomfort for the donor.

Therefore, we aimed to improving CMV-specific T cell isolation from G-CSF mobilized donors using MHCmultimers. In the present study, we have developed a method to avoid non-specific binding of multimers to potentially damaging cell subsets by using a physical procedure based on plastic adherence [28]. In this way, we have managed to minimize the non-specific binding of multimers and eventually obtain a more pure cellular product safer for infusion.

\section{Methods}

\section{Donor population and ethical statement}

This study was approved by the Institutional Review Board at Complejo Hospitalario de Navarra ( $\mathrm{CHN})$, and all donors gave informed consent prior to enrolment.

11 subjects who were stem cell donors at CHN for allo-HSCT were recruited. All were CMV-seropositive and carried the HLA-A*02:01 allele. HLA-I typing was done in the Immunology Unit and the serological analysis for CMV was obtained from the Microbiology Service of the CHN.

\section{PBSC mobilization and collection}

Cells were collected from donors who received 10 $\mu \mathrm{g} / \mathrm{kg} /$ day of recombinant G-CSF (Filgrastim, Sandoz
Biopharmaceuticals, Paris, France) every 12 hours starting five days before collection. Leukapheresis were performed with a COBE Spectra continuous flow blood cell separator (COBE Spectra apheresis system, Caridian BCT, Lakewood, CO, USA). Cell products, anticoagulated with ACD-A, were collected with a $1.1 \mathrm{ml} / \mathrm{min}$ flux in a $500 \mathrm{ml}$ container, from which an aliquot of $0.5 \mathrm{ml}$ was used to perform the experiments. Peripheral blood mononuclear cells (PBMCs) were isolated by Ficoll-Paque density gradient centrifugation (GE Healthcare Bio-Sciences, Uppsala, Sweden) and counted in Neubauer hemocytometer using 0.4\% trypan blue staining (Gibco, Carlsbad, CA).

\section{Enrichment of lymphocyte populations by plastic adherence}

$2.25 \times 10^{7}$ cells were suspended in $45 \mathrm{ml}$ of X-VIVO 15 Serum-free cell medium w/o supplements (Lonza, Basel, Switzerland) in a sterile $225 \mathrm{~cm}^{2}$ A/N flask with CellBIND Surface (Corning, Corning, NY) for 1 hour at $37^{\circ}$ $\mathrm{C}$ and $5 \% \mathrm{CO}_{2}$. Non-adherent cells were carefully collected by aspiration to avoid the disruption of the adherent cellular populations. Obtained cells were washed with Dulbecco's phosphate buffered saline (dPBS, SigmaAldrich, St. Louis, MO) before quantification and cytometric analysis.

\section{Phenotypic characterization of unmanipulated PBMCs and non-adherent cell product}

Fresh G-CSF mobilized PBMCs and the cellular harvest obtained after adherent cell removal were phenotypically characterized.

\section{Characterization of leukocyte subpopulations}

$1 \times 10^{6}$ cells were stained with anti-human CD3-V450 (BD Biosciences, San Jose, USA), CD8-FITC (BioLegend, San Diego, USA), CD14-PE (BioLegend), CD45-PerCPCy5.5 (BioLegend), and CD4-APC (BioLegend). Incubation was carried out for 15 minutes in the dark, cells were washed once and resuspended in dPBS prior to cytometer acquisition.

\section{$C M V$-specific CD8+ T cell quantification}

$5 \mu \mathrm{l}$ of PE-labelled Pentamer (PM; HLA-A*0201/CMV Pentamer, Proimmune, Oxford, United Kingdom) was added to $1 \times 10^{6}$ cells in a final volume of $50 \mu \mathrm{l}$. After an incubation of 10 minutes in the dark, cells were stained with CD3-V450, CD8-FITC, 7-AAD (BD), and CD45APC-H7 (BD). Samples were incubated with monoclonal antibodies for 15 minutes in the dark, washed once and resuspended in $\mathrm{dPBS}$ prior to cytometer acquisition.

\section{CMV-specific T cell selection}

From 5 G-CSF mobilized PBMCs before and after the adherent cell removal, $1 \times 10^{7}$ cells were stained with $50 \mu \mathrm{l}$ 
PE-labelled PM during 20 minutes at $4^{\circ} \mathrm{C}$ in the dark. After a wash, $20 \mu \mathrm{l}$ of anti-PE microbeads (Miltenyi Biotec, Bergisch Gladbach, Germany) were added to a final volume of $80 \mu \mathrm{l}$, followed by 20 minute incubation at $4^{\circ} \mathrm{C}$ in the dark. Afterwards, PM+ cells were isolated using a Possel_ds selection program on an AutoMACS Pro separator (Miltenyi Biotec).

\section{Acquisition and analysis by Flow Cytometry}

Samples were acquired in a FACSCanto II equipment (BD), FACSDiva 6.0 software (BD) was used for acquisition process and FlowJo version 10 (TreeStar Inc., Ashland, OR, USA) for cellular analysis. For the quantification of leukocyte subpopulations 50,000 total events were acquired, and $\mathrm{CD} 3+\mathrm{CD} 8+, \mathrm{CD} 3+\mathrm{CD} 4+$, and $\mathrm{CD} 14+$ frequencies were defined. For the CMV-specific T cell quantification 500,000 total events were acquired, and frequencies of total $\mathrm{AAD}+$ and $\mathrm{PM}+\mathrm{CD} 3+\mathrm{CD} 8+$ were determined. Only cells clustering with forward and side scatter properties of leukocyte subpopulations were included in the analysis, and the percentages were given from the CD45+ cell gate.

\section{Statistical analysis}

Data are represented as median (IQR). Wilcoxon signedrank test was used for paired comparisons and the significance level was fixed to $\mathrm{p}<0.05$. Statistical analysis was done using SPSS17 software package.

\section{Results}

CD8+ cell enrichment and unwanted cell depletion after adherence

47.8\% (36.0 - 55.0) of all PBMCs present in the mobilized apheresis expressed the CD14 marker. After the adherence process, CD14+ cells were significantly reduced to $2.1 \%(1.3-6.1)(\mathrm{p}=0.005)$.

In the original sample, $24.0 \%(18.0$ - 37.1) expressed CD3+, from which $17.7 \%(6.8$ - 25.1) were CD8+ and $12.5 \%(11.4$ - 19.4) were CD4+ cells. In the non-adherent cellular product CD3+ cells were significantly increased to $69.9 \%(31.9$ - 79.2) $(\mathrm{p}=0.007)$ and CD8+ subpopulation accordingly rose to $35.2 \%(23.8-45.2)(\mathrm{p}=0.009)$. CD4+ cell percentage remained at $19.3 \%$ (16.6 - 29.6), without reaching statistical significance $(\mathrm{p}>0.05)$ (Figure 1a,b, Table 1).

Percentages of different cell population recovery rates were calculated comparing the absolute number before adherence and the cells recovered in the non-adherent cellular fraction. 98.5\% (96.3 - 99.6) of CD14+ cells from the unmanipulated PBMC sample were lost after the adherence process. In comparison, 63.7\% (33.9 - 70.0) of the $\mathrm{T}$ lymphocyte population were collected in the nonadherent fraction, while $65.1 \%(31.9-81.3)$ and $53.2 \%$
(29.2 - 62.6) of the CD8+ and CD4+ cells were recovered, respectively.

7-AAD dye was used to assess cell viability before and after adherence. In the original mobilized sample 98.0\% (95.6 - 98.5) of cells were viable, whereas after adherence the viability was similar, $96.0 \%(93.4-97.8)$ ( $p>0.05)$.

\section{CMV-specific T cell enrichment and non-specific binding loss by plastic adherence}

Prior to adherence $0.14 \%(0.06-0.62)$ of PBMCs were specific for CMV (CD3+CD8+PM+), whereas after the adherence process this subpopulation was enriched to $0.65 \%$ $(0.24-1.51)(\mathrm{p}=0.003)$ in the non-adherent fraction (Figure 2, Table 1). The recovery rate of CMV-specific CTLs in the adherence process was $84.6 \%$ (56.3 - 88.7).

In the same way, the non-specific binding of multimers to unwanted CD8- cells was diminished. In the original apheresis sample $0.56 \%(0.41-0.86)$ CD8-PM+ were detected, while after adherence the non-specific CD8-PM+ cells were reduced to $0.16 \%(0.12-0.37) \quad(p=0.003)$.

\section{Optimization of CMV-specific T cell isolation by magnetic selection}

The purity of the obtained sample was determined as the percentage of PM+ cells in the product, and the yield was defined as the absolute number of $\mathrm{PM}+$ cells present in the positive fraction as a proportion of the absolute number of $\mathrm{PM}+$ cells in the sample before isolation. Using unmanipulated PBMCs, the median purity of the cellular product was $20.8 \%(6.9-61.7)$ and the yield was $38.6 \%(32.9$ - 44.8). In comparison, the purity of the positive fraction of the isolation using the non-adherent fraction was significantly increased to $76.0 \%$ (32.7 83.7) $(\mathrm{p}=0.043)$ while the yield was $42.1 \%(23.4-84.1)$ (p > 0.05) (Figure 3a,b, Table 1).

\section{Discussion}

Alloreactive donor effector cells have been identified as key players in the $\mathrm{GvH}$ reaction $[29,30]$. In this sense, donor derived monocytes have been implicated in the pathophysiology of clinical GvHD [31,32]. Therefore, it is important to assure that the product to be adoptively transferred contains a pure virus-specific $\mathrm{T}$ cell population with high specificity.

Since the generation of anti-viral cell products from G-CSF mobilized apheresis samples offers great logistical advantages especially in the unrelated donor setting, we assessed the direct isolation of CMV-specific CTL from G-CSF mobilized PBMCs using MHC-multimers. Donors that participated in this study were mobilized with a biosimilar of G-CSF, with similar effects in comparison to original G-CSF [33]. However, in our first approaches we found a high proportion of $\mathrm{MHC}$-multimer binding to CD8- cells and a low purity in the isolated cell 


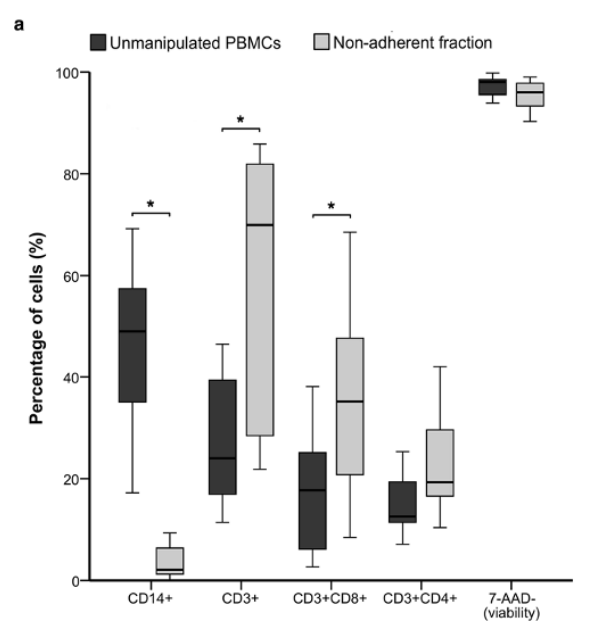

b
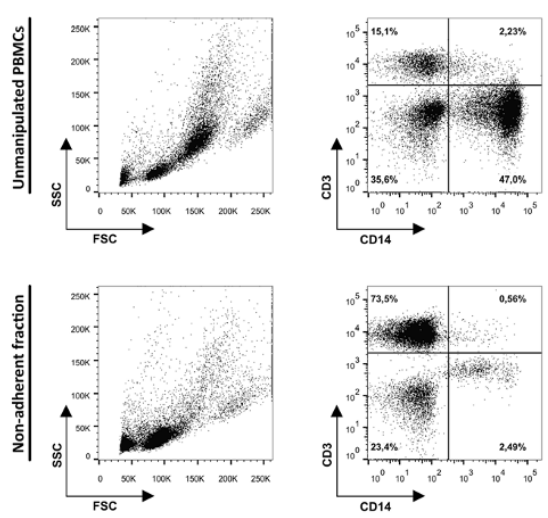

Figure 1 Phenotypic analysis of cells before and after the adherence process. Plastic adherence method was applied to PBMCs from G-CSF mobilized donors ( $n=11)$ and CD14, CD3, CD8, CD4 and 7-ADD expression of the unmanipulated PBMCs and the non-adherent cells were analyzed by flow cytometry (a). Representative figure of the products before and after the adherent process (b). Cells are presented from the CD45+ cell gate.

product. In this sense, recent studies have shown that background levels of multimer staining are higher in GCSF mobilized samples compared to non-mobilized ones [22]. Multimers can join non-specifically to Fc receptors (FcRs) [34], that are mainly expressed on monocytes, dendritic cells, neutrophils, and eosinophils [35]. The upregulation of FcRI and FcRIII in neutrophils and monocytes induced by G-CSF treatment [36,37] could explain the high background levels described in MHC-multimer staining when G-CSF mobilized samples are used. Furthermore, multimers have been described to bind nonspecifically to CD14+ cells [34,38], and G-CSF treatment in healthy individuals results in an increased expression of the CD14 antigen on neutrophils while maintaining its expression on monocytes [39,40]. Therefore, we found the necessity to develop an approach that could avoid the non-specific binding of multimers and the subsequent isolation of potentially alloreactive cells.

A simple process based on plastic adherence reduced all unwanted cellular subsets from mobilized samples due to the fact that hematopoietic progenitors [41], monocytes [42], and neutrophils [39,43], enriched in peripheral blood in response to G-CSF treatment, have the ability to adhere to plastic surfaces. At the same time the proportion of CTLs, which do not adhere to the plastic, was significantly increased in the non-adherent product.

Table 1 Phenotypic characterization and CMV-specific CTL isolation of unmanipulated PBMCs and the non-adherent fraction

\begin{tabular}{|c|c|c|c|}
\hline & Unmanipulated PBMCs & Non-adherent fraction & $\mathrm{p}$ \\
\hline \multicolumn{4}{|c|}{ Leukocyte subpopulations } \\
\hline CD14+ cells & $47.8 \%(36.0-55.0)$ & $2.1 \%(1.3-6.1)$ & 0.005 \\
\hline T lymphocytes (CD3+) & $24.0 \%(18.0-37.1)$ & $69.9 \%(31.9-79.2)$ & 0.007 \\
\hline CTLs (CD3 + CD8+) & $17.7 \%(6.8-25.1)$ & $35.2 \%(23.8-45.2)$ & 0.009 \\
\hline Helper T cells $(C D 3+C D 4+)$ & $12.5 \%(11.4-19.4)$ & $19.3 \%(16.6-29.6)$ & 0.208 \\
\hline \multirow[t]{2}{*}{ Viability (7-AAD-) } & $98.0 \%(95.6-98.5)$ & $96.0 \%(93.4-97.8)$ & 0.066 \\
\hline & \multicolumn{2}{|c|}{ PM staining: specific and non-specific binding } & \\
\hline CMV-specific CTLs (CD3 + CD8 + PM+) & $0.14 \%(0.06-0.62)$ & $0.65 \%(0.24-1.51)$ & 0.003 \\
\hline \multirow[t]{2}{*}{ Non-specific PM binding (CD8-PM+) } & $0.56 \%(0.41-0.86)$ & $0.16 \%(0.12-0.37)$ & 0.003 \\
\hline & \multicolumn{2}{|c|}{ CMV-specific CTL isolation } & \\
\hline Purity & $20.8 \%(6.9-61.7)$ & $76.0 \%(32.7-83.7)$ & 0.043 \\
\hline Yield & $38.6 \%(32.9-44.8)$ & $42.1 \%(23.4-84.1)$ & 0.893 \\
\hline
\end{tabular}

Cell subsets, CMV-specific CTLs and non-specific PM staining were analyzed in the unmanipulated PBMC sample and in the non-adherent cells ( $n=11)$. CMVspecific CTLs were isolated from unmanipulated PBMCs and non-adherent fraction, and purity and yield of the obtained cellular product were determined $(n=5)$. Comparison was done with the Wilcoxon signed-rank test and significance level was fixed to $p<0.05$. 


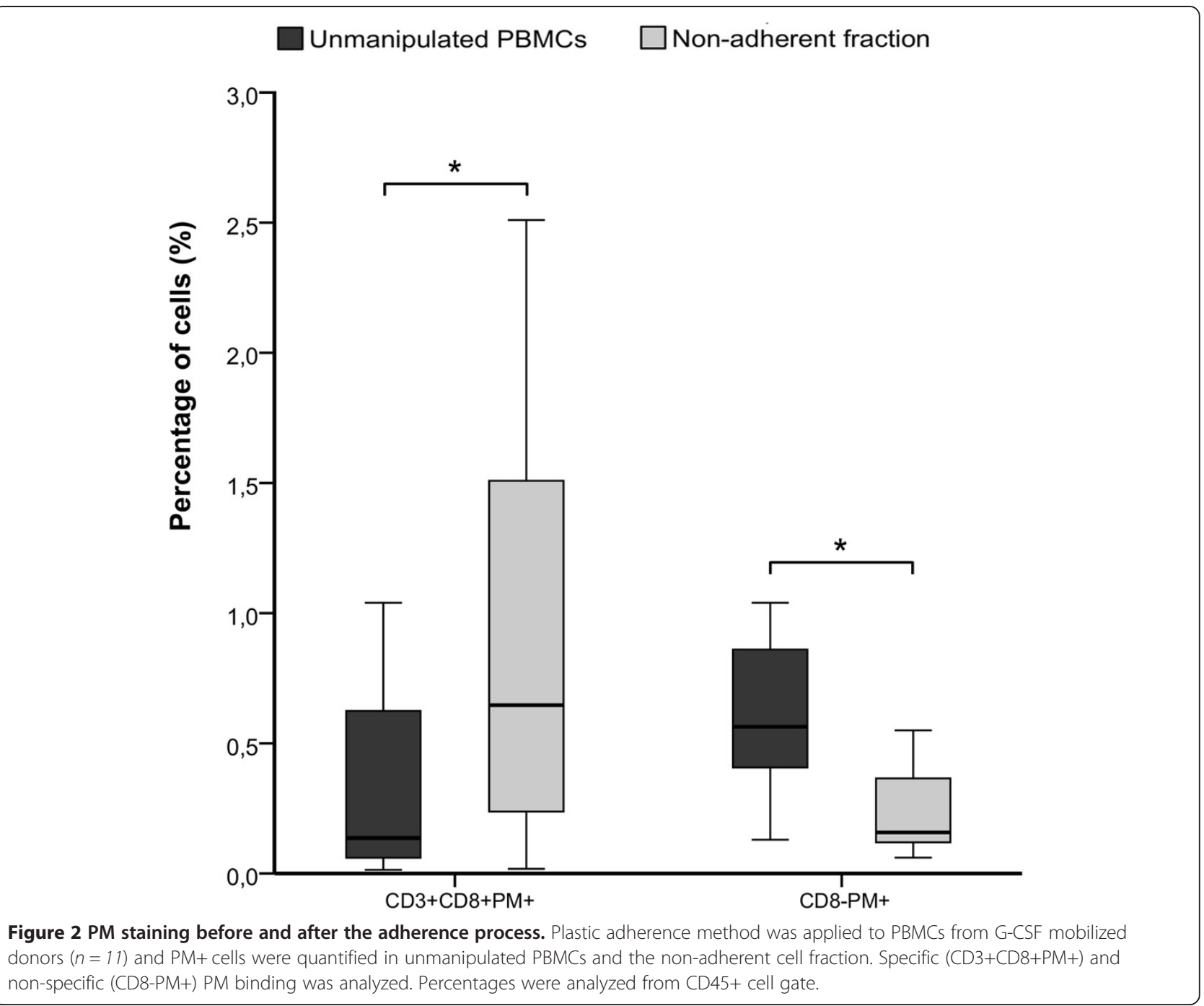

Accordingly, after the adherence process the sample was enriched in CMV-specific CTLs and the binding of the multimers to CD8- cells was reduced, which consequently provoked an increase in the efficacy of the subsequent CMV-specific T cell magnetic selection process.

Clinical protocols that infused CMV-specific CTLs obtained through MHC-multimer isolation to avoid CMV reactivation after allo-HSCT have described that an infusion of less than $1 \times 10^{4}$ cells $/ \mathrm{kg}$ resulted in a considerable expansion of CMV-specific CTLs in vivo and was able to control CMV viremia [11,12]. According to our results, these cell numbers could be manufactured from an aliquot of the original G-CSF mobilized PBSC graft (approximately $5 \mathrm{ml}$, depending on the cellularity and CMV-specific $\mathrm{T}$ cell percentage in the G-CSF mobilized harvest). However, for the routine applicability of the method described in this study, the adherence process would be more easily performed using Hyperflask devices (Corning), with a median of 8 flasks (range 2-13) necessary to obtain the required CMV-specific CTL numbers. At the same time, after the adherence process the multimer quantity required to isolate the same amount of specific cells would be reduced, with the associated decrease in the cost of the procedure.

\section{Conclusions}

In the present study we have addressed the high nonspecificity present in the $\mathrm{CMV}$-specific $\mathrm{T}$ cell isolation using MHC-multimers from G-CSF mobilized donors using an easy, safe and cheap physical procedure, which is readily translatable into the clinic by using Hyperflask devices and GMP grade MHC-multimers. The implementation of this simple method to use G-CSF mobilized PBMCs as starting material for the manufacture of antiviral cells, apart from reducing costs, would facilitate the accessibility of antigen-specific cellular products for adoptive immunotherapy following allo-HSCT, widening the 
a

Unmanipulated PBMCs $\square$ Non-adherent fraction

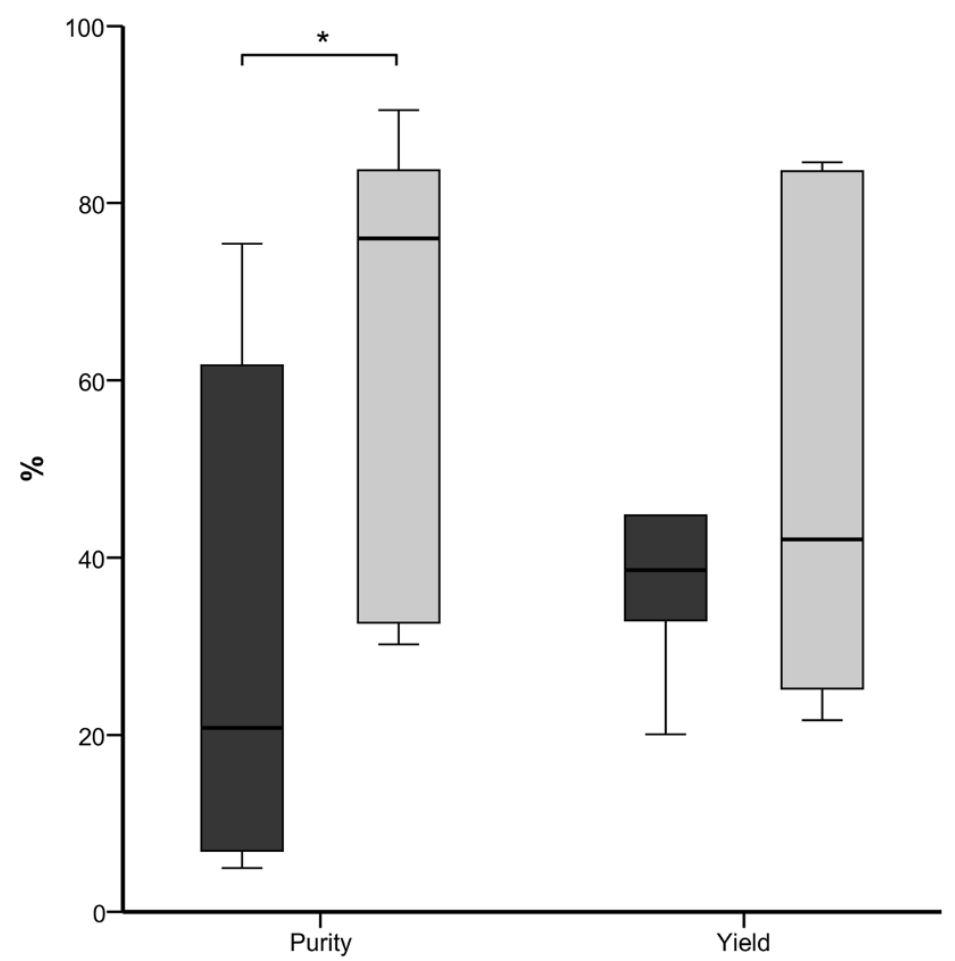

b
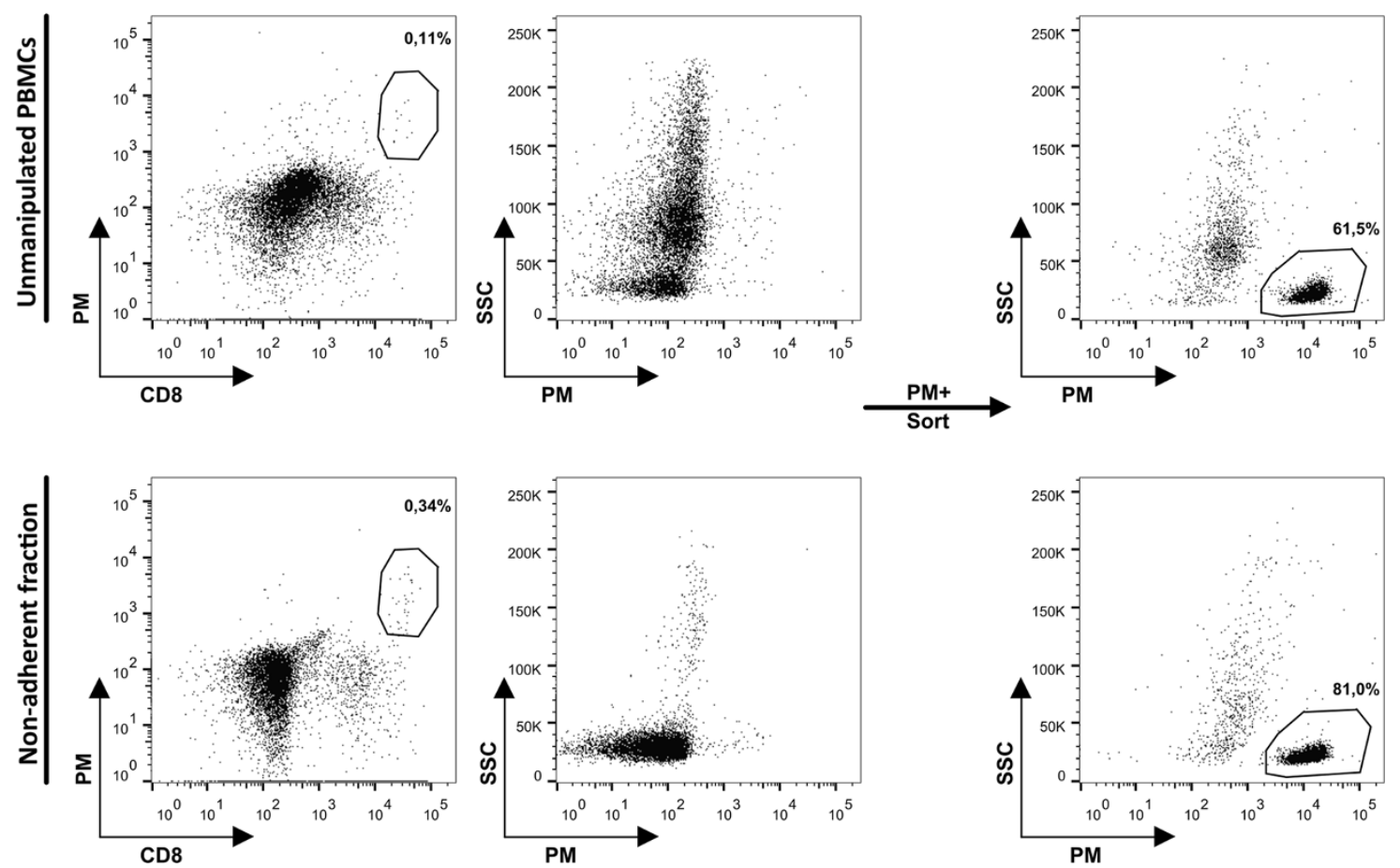

Figure 3 CMV-specific CTL isolation using Pentamer. CMV-specific CTLs were isolated from unmanipulated PBMCs and the non-adherent fraction using PM $(n=5)$ and the purity and yield of the process were determined (a). Representative histograms of CMV-specific CTL isolation (b). Displayed cells were previously gated on CD45+ cells. 
number of patients that could benefit from this successful therapy.

\section{Abbreviations}

Allo-HSCT: Allogeneic hematopoietic stem cell transplantation; CTL: Cytotoxic T cells; FcR: Fc receptor; G-CSF: Granulocyte-colony stimulating factor; GVHD: Graft versus host disease; HSC: Hematopoietic stem cell; PBSC: Peripheral blood stem cell; Th: Helper T cell.

\section{Competing interests}

MWL is a shareholder in Cell Medica, a clinical-stage cellular therapeutics company. The authors have declared that there are no financial conflicts of interest in regard to this work.

\section{Authors' contributions}

$L B, M C, N R$ and $E O$ conceived and designed the experiments. $L B$ and $M C$ performed the experiments. $L B, M C, C M, A Z$, EPV processed and analysed the data. LB wrote the manuscript with NR and EO. MWL and ERS contributed to the drafting of the manuscript. All authors read and approved the final manuscript.

\section{Authors' information}

Eduardo Olavarria and Natalia Ramirez are joint senior authors.

\section{Acknowledgements}

This work was supported by a research grant (PI10/00136) from Fondo de Investigaciones Sanitarias (FIS) granted by the Instituto de Salud Carlos III (ISCIII). LB is a recipient of APPICS Predoctoral Fellowship from Departamento de Salud del Gobierno de Navarra. MC is a recipient of PFIS Predoctoral Fellowship from ISCIII. CM is a recipient of ANABASID Postdoctoral Fellowship from Departamento de Educación del Gobierno de Navarra. AZ is a recipient of a Post-MIR Fellowship from Complejo Hospitalario de Navarra $(\mathrm{CHN})$. We sincerely thank Department of Haematology staff from Complejo Hospitalario de Navarra (Spain).

\section{Author details}

'Oncohematology Research Group, Navarrabiomed - Miguel Servet Foundation, Irunlarrea 3, 31008 Pamplona, Spain. ${ }^{2}$ Department of Haematology, University College London Medical School, University College London, London, UK. ${ }^{3}$ Department of Haematology, Complejo Hospitalario de Navarra, Navarra Health Service, Pamplona, Spain.

\section{Received: 27 August 2014 Accepted: 4 November 2014}

\section{Published online: 19 November 2014}

\section{References}

1. Copelan EA: Hematopoietic stem-cell transplantation. N Engl J Med 2006, 354:1813-1826.

2. Passweg JR, Baldomero H, Peters C, Gaspar HB, Cesaro S, Dreger P, Duarte RF, Falkenburg JH, Farge-Bancel D, Gennery A, Halter J, Kröger N, Lanza F, Marsh J, Mohty M, Sureda A, Velardi A, Madrigal A: Hematopoietic SCT in Europe: data and trends in 2012 with special consideration of pediatric transplantation. Bone Marrow Transplant 2014, 49:744-750.

3. Anderlini P, Champlin RE: Biologic and molecular effects of granulocyte colony-stimulating factor in healthy individuals: recent findings and current challenges. Blood 2008, 111:1767-1772.

4. Christopher MJ, Link DC: Regulation of neutrophil homeostasis. Curr Opin Hematol 2007, 14:3-8.

5. Imamura R, Miyamoto T, Yoshimoto G, Kamezaki K, Ishikawa F, Henzan H, Kato K, Takase K, Numata A, Nagafuji K, Okamura T, Sata M, Harada M, Inaba S: Mobilization of human lymphoid progenitors after treatment with granulocyte colony-stimulating factor. J Immunol 2005, 175:2647-2654.

6. Meijer E, Boland GJ, Verdonck LF: Prevention of cytomegalovirus disease in recipients of allogeneic stem cell transplants. Clin Microbiol Rev 2003, 16:647-657.

7. Riddell SR, Watanabe KS, Goodrich JM, Li CR, Agha ME, Greenberg PD: Restoration of viral immunity in immunodeficient humans by the adoptive transfer of T cell clones. Science 1992, 257:238-241.

8. Peggs KS, Verfuerth S, Pizzey A, Chow SL, Thomson K, Mackinnon S: Cytomegalovirus-specific $\mathrm{T}$ cell immunotherapy promotes restoration of durable functional antiviral immunity following allogeneic stem cell transplantation. Clin Infect Dis 2009, 49:1851-1860.

9. Peggs KS, Thomson K, Samuel E, Dyer G, Armoogum J, Chakraverty R, Pang K, Mackinnon S, Lowdell MW: Directly Selected Cytomegalovirus-Reactive Donor T Cells Confer Rapid and Safe Systemic Reconstitution of Virus-Specific Immunity Following Stem Cell Transplantation. Clin Infect Dis 2011, 52:49-57.

10. Blyth E, Clancy L, Simms R, Ma CK, Burgess J, Deo S, Byth K, Dubosq MC, Shaw PJ, Micklethwaite KP, Gottlieb DJ: Donor-derived CMV-specific T cells reduce the requirement for CMV-directed pharmacotherapy after allogeneic stem cell transplantation. Blood 2013, 121:3745-3758.

11. Cobbold M, Khan N, Pourgheysari B, Tauro S, McDonald D, Osman H, Assenmacher M, Billingham L, Steward C, Crawley C, Olavarria E, Goldman J, Chakraverty R, Mahendra P, Craddock C, Moss PA: Adoptive transfer of cytomegalovirus-specific CTL to stem cell transplant patients after selection by HLA-peptide tetramers. J Exp Med 2005, 202:379-386.

12. Uhlin M, Gertow J, Uzunel M, Okas M, Berglund S, Watz E, Brune M, Ljungman P, Maeurer M, Mattsson J: Rapid salvage treatment with virus-specific T cells for therapy-resistant disease. Clin Infect Dis 2012, 55:1064-1073.

13. Ramirez N, Beloki L, Ciaurriz M, Rodriguez-Calvillo M, Escors D, Mansilla C, Bandres $E$, Olavarria E: Impact of T cell selection methods in the success of clinical adoptive immunotherapy. Cell Mol Life Sci 2014, 71:1211-1224.

14. Peggs K, Verfuerth S, Mackinnon S: Induction of cytomegalovirus (CMV)-specific T-cell responses using dendritic cells pulsed with CMV antigen: a novel culture system free of live CMV virions. Blood 2001, 97:994-1000.

15. Leen AM, Myers GD, Sili U, Huls MH, Weiss H, Leung KS, Carrum G, Krance RA, Chang CC, Molldrem JJ, Gee AP, Brenner MK, Heslop HE, Rooney CM, Bollard CM: Monoculture-derived T lymphocytes specific for multiple viruses expand and produce clinically relevant effects in immunocompromised individuals. Nat Med 2006, 12:1160-1166.

16. Bissinger AL, Rauser G, Hebart H, Frank F, Jahn G, Einsele H: Isolation and expansion of human cytomegalovirus- specific cytotoxic $\mathrm{T}$ lymphocytes using interferon-gamma secretion assay. Exp Hematol 2002, 30:1178-1184.

17. Neudorfer J, Schmidt B, Huster KM, Anderl F, Schiemann M, Holzapfel G, Schmidt T, Germeroth L, Wagner H, Peschel C, Busch DH, Bernhard H: Reversible HLA multimers (Streptamers) for the isolation of human cytotoxic $T$ lymphocytes functionally active against tumor- and virus-derived antigens. J Immunol Methods 2007, 320:119-131.

18. Ramirez N, Olavarria E: Viral-specific adoptive immunotherapy after allo-SCT: the role of multimer-based selection strategies. Bone Marrow Transplant 2013, 48:1265-1270.

19. Gattinoni L, Klebanoff CA, Palmer DC, Wrzesinski C, Kerstann K, Yu Z, Finkelstein SE, Theoret MR, Rosenberg SA, Restifo NP: Acquisition of full effector function in vitro paradoxically impairs the in vivo antitumor efficacy of adoptively transferred CD8+ T cells. J Clin Invest 2005, 115:1616-1626.

20. Shen X, Zhou J, Hathcock KS, Robbins P, Powell DJ Jr, Rosenberg SA, Hodes RJ: Persistence of tumor infiltrating lymphocytes in adoptive immunotherapy correlates with telomere length. J Immunother 2007, 30:123-129.

21. Kolen S, Dolstra H, van de Locht L, Braakman E, Schattenberg A, de Witte T, van de Wiel-van KE: Biodistribution and retention time of retrovirally labeled T lymphocytes in mice is strongly influenced by the culture period before infusion. J Immunother 2002, 25:385-395.

22. Bunse $C E$, Borchers $S$, Varanasi PR, Tischer S, Figueiredo $C$, Immenschuh $S$, Kalinke U, Kohl U, Goudeva L, Maecker-Kolhoff B, Ganser A, Blasczyk R, Weissinger EM, Eiz-Vesper B: Impaired Functionality of Antiviral T Cells in G-CSF Mobilized Stem Cell Donors: Implications for the Selection of CTL Donor. PLoS One 2013, 8:e77925.

23. Rutella S, Zavala F, Danese S, Kared H, Leone G: Granulocyte colonystimulating factor: a novel mediator of T cell tolerance. J Immunol 2005, 175:7085-7091.

24. Rutella S, Pierelli L, Bonanno G, Sica S, Ameglio F, Capoluongo E, Mariotti A, Scambia G, d'Onofrio G, Leone G: Role for granulocyte colony-stimulating factor in the generation of human T regulatory type 1 cells. Blood 2002, 100:2562-2571.

25. Toh HC, Sun L, Soe Y, Wu Y, Phoon YP, Chia WK, Wu J, Wong KY, Tan P: G-CSF induces a potentially tolerant gene and immunophenotype profile in T cells in vivo. Clin Immunol 2009, 132:83-92.

26. Samuel ER, Newton K, Mackinnon S, Lowdell MW: Successful isolation and expansion of CMV-reactive T cells from G-CSF mobilized donors that retain a strong cytotoxic effector function. Br J Haematol 2013, 160:87-100. 
27. Clancy LE, Blyth E, Simms R, Micklethwaite KP, Kris Ma CK, Burgess J, Antonenas V, Shaw PJ, Gottlieb DJ: CMV-specific cytotoxic T lymphocytes can be efficiently expanded from G-CSF mobilised haemopoietic progenitor cell products ex vivo and safely transferred to stem cell transplant recipients to facilitate immune reconstitution. Biol Blood Marrow Transplant 2013, 19:725-734.

28. Doubrovina E, Oflaz-Sozmen B, Prockop SE, Kernan NA, Abramson S, TeruyaFeldstein J, Hedvat C, Chou JF, Heller G, Barker JN, Boulad F, Castro-Malaspina H, George D, Jakubowski A, Koehne G, Papadopoulos EB, Scaradavou A, Small TN, Khalaf $R$, Young JW, O'Reilly RJ: Adoptive immunotherapy with unselected or EBV-specific T cells for biopsy-proven EBV + lymphomas after allogeneic hematopoietic cell transplantation. Blood 2012, 119:2644-2656.

29. Socie G, Blazar BR: Acute graft-versus-host disease: from the bench to the bedside. Blood 2009, 114:4327-4336.

30. Coghill JM, Sarantopoulos S, Moran TP, Murphy WJ, Blazar BR, Serody JS: Effector CD4+ T cells, the cytokines they generate, and GVHD: something old and something new. Blood 2011, 117:3268-3276.

31. Fowler DH, Foley J, Whit-Shan Hou J, Odom J, Castro K, Steinberg SM, Gea-Banacloche J, Kasten-Sportes C, Gress RE, Bishop MR: Clinical "cytokine storm" as revealed by monocyte intracellular flow cytometry: correlation of tumor necrosis factor alpha with severe gut graft-versus-host disease. Clin Gastroenterol Hepatol 2004, 2:237-245.

32. Arpinati M, Chirumbolo G, Marzocchi G, Baccarani M, Rondelli D: Increased donor CD86 + CD14+ cells in the bone marrow and peripheral blood of patients with chronic graft-versus-host disease. Transplantation 2008, 85:1826-1832

33. Bonig H, Becker PS, Schwebig A, Turner M: Biosimilar granulocyte-colonystimulating factor for healthy donor stem cell mobilization: need we be afraid? Transfusion 2014, in press.

34. Beloki L, Ciaurriz M, Mansilla C, Bandres E, Rodriguez-Calvillo M, Ramirez N, Olavarria E: The abrogation of TCR-independent interactions with human serum ensures a selective capture of therapeutic virus-specific CD8 T-cells by Multimer Technology in Adoptive Immunotherapy. $J$ Immunol Methods 2013, 396:168-172.

35. Nimmerjahn F, Ravetch JV: Fcgamma receptors: old friends and new family members. Immunity 2006, 24:19-28.

36. Repp R, Valerius T, Sendler A, Gramatzki M, Iro H, Kalden JR, Platzer E: Neutrophils express the high affinity receptor for lgG (Fc gamma Rl, CD64) after in vivo application of recombinant human granulocyte colony-stimulating factor. Blood 1991, 78:885-889.

37. Ohsaka A, Saionji K, Kuwaki T, Takeshima T, Igari J: Granulocyte colonystimulating factor administration modulates the surface expression of effector cell molecules on human monocytes. Br J Haematol 1995, 89:465-472.

38. Nagorsen D, Monsurro V, Wang E, Marincola FM: Characterization of CD8 (-) HLA class I/epitope tetrameric complexes binding T cells. J Immunother 2002, 25:379-384.

39. Spiekermann K, Roesler J, Emmendoerffer A, Elsner J, Welte K: Functional features of neutrophils induced by G-CSF and GM-CSF treatment: differential effects and clinical implications. Leukemia 1997, 11:466-478.

40. Kerst JM, de Haas M, van der Schoot CE, Slaper-Cortenbach IC, Kleijer M, von dem Borne $A E$, van Oers RH: Recombinant granulocyte colonystimulating factor administration to healthy volunteers: induction of immunophenotypically and functionally altered neutrophils via an effect on myeloid progenitor cells. Blood 1993, 82:3265-3272.

41. Scott MA, Apperley JF, Jestice HK, Bloxham DM, Marcus RE, Gordon MY: Plastic-adherent progenitor cells in mobilized peripheral blood progenitor cell collections. Blood 1995, 86:4468-4473.

42. Elkord E, Williams PE, Kynaston H, Rowbottom AW: Human monocyte isolation methods influence cytokine production from in vitro generated dendritic cells. Immunology 2005, 114:204-212.

43. Ginis I, Zaner K, Wang JS, Pavlotsky N, Tauber Al: Comparison of actin changes and calcium metabolism in plastic- and fibronectin-adherent human neutrophils. J Immunol 1992, 149:1388-1394.

doi:10.1186/s12967-014-0317-8

Cite this article as: Beloki et al: CMV-specific T cell isolation from G-CSF mobilized peripheral blood: depletion of myeloid progenitors eliminates non-specific binding of MHC-multimers. Journal of Translational Medicine 2014 12:317.

\section{Submit your next manuscript to BioMed Central and take full advantage of:}

- Convenient online submission

- Thorough peer review

- No space constraints or color figure charges

- Immediate publication on acceptance

- Inclusion in PubMed, CAS, Scopus and Google Scholar

- Research which is freely available for redistribution 